\title{
Pentoxifylline Reduces Regional Inflammatory and Ventilatory Disturbances in Meconium-Exposed Piglet Lungs
}

\author{
KALLE KORHONEN, AARO KIURU, ERKKI SVEDSTRÖM, AND PEKKA KÄÄPÄ
}

Research Centre of Applied and Preventive Cardiovascular Medicine [K.K., P.K.], University of Turku, FIN-20520 Turku, Finland; Department of Pediatrics [K.K., P.K.], Turku University Central Hospital, FIN-20520 Turku, Finland; and Department of Diagnostic Radiology [A.K., E.S.], Turku University

Central Hospital, FIN-20520 Turku, Finland

\begin{tabular}{|c|c|}
\hline \multicolumn{2}{|c|}{ ABSTRACT } \\
\hline $\begin{array}{l}\text { Neonatal meconium aspiration frequently produces severe } \\
\text { respiratory distress, which is associated with patchy pulmonary } \\
\text { neutrophil influx and inflammatory injury. To examine the effects } \\
\text { of pentoxifylline (PTX), a potent anti-inflammatory agent, on } \\
\text { regional pulmonary inflammation and ventilation after meco- } \\
\text { nium aspiration, we studied } 17 \text { anesthetized and ventilated neo- } \\
\text { natal piglets (age }<2 \mathrm{~d} \text { ) for } 12 \mathrm{~h} \text {. After unilateral intrapulmonary } \\
\text { instillation of meconium, PTX treatment was started in nine } \\
\text { animals, and eight untreated animals served as controls. Bron- } \\
\text { choalveolar lavage (BAL) fluid and lung tissue were studied for } \\
\text { inflammatory variables at the end of the study, and changes in } \\
\text { regional ventilation were serially analyzed with a dynamic pul- } \\
\text { monary X-ray imaging method. Meconium insufflation increased } \\
\text { BAL fluid total cell, neutrophil, and macrophage counts and } \\
\text { tumor necrosis factor- } \alpha \text { (TNF- } \alpha \text { ) and protein concentrations as } \\
\text { well as lung tissue myeloperoxidase activity in the instilled } \\
\text { lungs, compared with the noninstilled side. PTX treatment pre- } \\
\text { vented the increase of BAL fluid alveolar macrophage count and } \\
\text { TNF- } \alpha \text { and protein concentrations in the meconium-instilled } \\
\text { lungs but had no significant effect on the pulmonary neutrophil } \\
\text { accumulation. Ventilation of the meconium-insulted lung was }\end{array}$ & $\begin{array}{l}\text { initially disturbed similarly in both study groups, but PTX ad- } \\
\text { ministration prevented the sustained local ventilatory perturba- } \\
\text { tion at } 4,6 \text {, and } 12 \mathrm{~h} \text { after meconium instillation. The results thus } \\
\text { indicate that PTX treatment may attenuate meconium-induced } \\
\text { regional ventilation derangements, mainly through its effects on } \\
\text { local alveolar macrophages and TNF- } \alpha \text { production as well as } \\
\text { alveolocapillary permeability rather than via significant preven- } \\
\text { tion of accumulation of active neutrophils in the insulted lungs. } \\
\text { (Pediatr Res 56: 901-906, 2004) } \\
\text { Abbreviations } \\
\text { AaDO, alveolo-arterial oxygen difference } \\
\text { AMP, range of variation of pulmonary transmittance } \\
\text { AVG, average of pulmonary transmittance } \\
\text { BAL, bronchoalveolar lavage } \\
\text { DPI, dynamic pulmonary imaging } \\
\text { MAS, meconium aspiration syndrome } \\
\text { PMN, polymorphonuclear neutrophil } \\
\text { PTX, pentoxifylline } \\
\text { R/L, right to left lung ratio } \\
\text { TNF- } \alpha \text {, tumor necrosis factor- } \alpha\end{array}$ \\
\hline
\end{tabular}

Perinatal aspiration of meconium frequently produces respiratory failure with hypoxemia, hypercapnia, and acidosis in the newborn infant and may be complicated by air leaks, pulmonary hypertension, hypoxic organ damage, and long-term pulmonary sequelae $(1,2)$. The pathophysiology of the meconium aspiration syndrome (MAS) is complex and includes initial mechanical obstruction of the airways, ventilation/perfusion mismatch, surfactant inactivation, and progressively develop-

Received June 2, 2003; accepted May 5, 2004.

Correspondence: Kalle Korhonen, M.D., Research Centre of Applied and Preventive Cardiovascular Medicine (CAPC), Kiinamyllynkatu 10, FIN-20520 Turku, Finland; email: kalle.korhonen@utu.fi

The study was financially supported by the Foundation for Pediatric Research, Finland, and Sigrid Juselius Foundation.

DOI: 10.1203/01.PDR.0000145256.19073.E4 ing inflammatory lung injury (1-6). Aspirated meconium may directly damage the alveolar-capillary membrane and may also augment pulmonary injury through activation of alveolar macrophages, inflammatory cytokine production, and accumulation of polymorphonuclear neutrophils (PMNs) $(1,2,6,7)$. Whereas the uneven distribution of inhaled meconium leads to localized areas of injury with variable aeration of the affected lungs, the contribution and mechanisms of the patchy inflammatory processes to the pulmonary dysfunction induced by meconium aspiration is still unclear. Consequently, the therapeutic value of anti-inflammatory agents in the management of MAS remains controversial $(6,8-12)$.

Pentoxifylline (PTX), a methylxanthine derivative and phosphodiesterase inhibitor, has hemorheologic and immunomodulatory properties and is proposed to have a therapeutic role in 
the suppression of inflammatory reactions in different tissues, including the lungs $(13,14)$. Increasing evidence suggests that PTX administration decreases the activation of inflammatory cells and inhibits production of proinflammatory cytokines within the insulted lungs (14-17). These anti-inflammatory effects, together with reduction of high-permeability pulmonary edema, may contribute to attenuation of several forms of acute lung injury after PTX treatment (16-18). Consequently, there are experimental data indicating that PTX is able to attenuate endotoxin, oxygen, tumor necrosis factor (TNF), saline lavage, and acid aspiration-induced acute lung injuries (19-23), but its effect on the inflammatory injury in the meconium-exposed lungs is still unknown. We hypothesized, that the regional inflammatory reactions and the resulting local ventilatory disturbances in the neonatal lungs after meconium aspiration could be diminished by the anti-inflammatory properties of PTX. Therefore, we induced a unilateral lung injury with local meconium instillation, as previously described (24), and examined the effects of PTX on pulmonary inflammation and ventilatory function in both lungs.

\section{METHODS}

Animal preparation. Seventeen newborn (age $<2 \mathrm{~d}$; weight $\sim 2 \mathrm{~kg}$ ) piglets were studied. Animals were sedated with diazepam $(1.5 \mathrm{mg} / \mathrm{kg}$ intramuscularly) and anesthetized with sodium pentobarbital $(30 \mathrm{mg} / \mathrm{kg}$ intravenously). Tracheotomy was performed, a $3.5-\mathrm{mm}$ internal diameter endotracheal tube was inserted with the distal tip located at least $1 \mathrm{~cm}$ proximal to the carina, and animals were placed on a pressure-controlled neonatal mechanical ventilator (Baby Bird; Bird Productions Corp., Palm Springs, CA). The initial respiratory settings were as follows: fraction of inspired oxygen 0.21 , rate 20 breaths/ min, peak inspiratory pressure $20 \mathrm{~cm} \mathrm{H}_{2} \mathrm{O}$, and positive end expiratory pressure $4 \mathrm{~cm} \mathrm{H}_{2} \mathrm{O}$. Anesthesia was maintained with a continuous i.v. infusion of sodium pentobarbital $\left(6 \mathrm{mg} \cdot \mathrm{kg}^{-1}\right.$ $\left.\cdot \mathrm{h}^{-1}\right)$. Paralysis was induced with i.v. pancuronium bromide $(0.3 \mathrm{mg} / \mathrm{kg})$ and maintained with a continuous infusion $(0.6 \mathrm{mg}$ $\left.\cdot \mathrm{kg}^{-1} \cdot \mathrm{h}^{-1}\right)$. A polyethylene catheter was inserted through the umbilical artery into the descending aorta to obtain blood gas samples and to continuously measure the blood pressure. Catheter insertion via the umbilical artery was not successful in four control piglets, and their arterial blood sampling thus was performed from the femoral artery. Alveolo-arterial oxygen difference $\left(\mathrm{AaDO}_{2}\right)$ was evaluated using the equation $\mathrm{AaDO}_{2}$ $=700 \times \mathrm{FIO}_{2}-\mathrm{PaCO}_{2} / 0.8-\mathrm{PaO}_{2}(\mathrm{~mm} \mathrm{Hg})$, where $\mathrm{FIO}_{2}$ is fraction of inspired oxygen, $\mathrm{PaO}_{2}$ is arterial oxygen tension $\left(\mathrm{mm} \mathrm{Hg}\right.$ ), and $\mathrm{PaCO}_{2}$ is arterial carbon dioxide tension $(\mathrm{mm}$ $\mathrm{Hg})$.

Experiments were approved by the Committee of Animal Care in Research of the University of Turku. Animals were cared for in accordance with procedures outlined in the "Guide for the Care and Use of Laboratory Animals" (National Institutes of Health Publications No. 85-23).

Meconium preparation. Meconium was collected from the first stools of several healthy term human neonates. The samples were initially frozen and later pooled, lyophilized, and irradiated for sterility. Endotoxin was quantified using Limulus
Amebocyte Lysate assay (LAL Kinetic-QCL, 50-650 U; BioWhittaker/Camprex, Walkersville, MD). Before the experiment, meconium was diluted with sterile saline to a concentration of $65 \mathrm{mg} / \mathrm{mL}$, clinically corresponding to thick meconium in amniotic fluid (25).

Study protocol. As described earlier (24), after $1 \mathrm{~h}$ of stabilization, a bolus $(1.5 \mathrm{~mL} / \mathrm{kg})$ of meconium was instilled into the lower lobe of the right lung. In a supine position, an $\mathrm{x}$-ray positive catheter was inserted through the intubation tube under fluoroscopic guidance into the right main bronchus, $2 \mathrm{~cm}$ distal from the tracheal bifurcation. The piglets then were turned to the right lateral position, and meconium was instilled slowly through the catheter. Remaining of meconium in the right lung was confirmed in preliminary roentgenographic studies by unilateral instillation of meconium mixed with barium, and in the present study macroscopically and histologically after each experiment. After 15 min of ventilation, the animals were turned back to the supine position for the rest of the study. An i.v. PTX bolus $(20 \mathrm{mg} / \mathrm{kg})$, followed by continuous infusion $\left(20 \mathrm{mg} \cdot \mathrm{kg}^{-1} \cdot \mathrm{h}^{-1}\right)$, was started in nine piglets at $15 \mathrm{~min}$ after the pulmonary insult. Control piglets $(n=8)$ with unilateral intrapulmonary meconium instillation received the same amount of vehicle. Inspired oxygen was adjusted to keep $\mathrm{PaO}_{2}$ between 8 and $12 \mathrm{kPa}$. After the stabilization period, ventilatory frequency, peak inspiratory pressure, and positive end expiratory pressure were kept constant throughout the study. Body temperature was maintained $>38^{\circ} \mathrm{C}$ with a radiant warmer. Five percent glucose in saline was infused intravenously at $6 \mathrm{~mL} \cdot \mathrm{kg}^{-1} \cdot \mathrm{h}^{-1}$. Regional ventilation was assessed noninvasively with a dynamic pulmonary imaging (DPI) method before and $30 \mathrm{~min}$ and $1,2,4,6$, and $12 \mathrm{~h}$ after meconium instillation. At the end of the study, the animals were killed with an overdose of potassium chloride, and bronchoalveolar lavage (BAL) of both lungs was performed separately and samples of lung tissue were obtained.

Inflammatory variables. At the end of the study, the heart and lungs were removed en bloc. Both main bronchi were alternately tied, and lavage of both lungs was performed separately by instillation of $15 \mathrm{~mL}$ of normal saline three times to each lung followed by immediate aspiration. BAL fluid was centrifuged ( $350 \mathrm{G}, 4^{\circ} \mathrm{C}$ for $10 \mathrm{~min}$ ), and total alveolar cell counts from cellular debris were performed in Bürker chamber. Differential cell counts were performed after cytocentrifugation and May-Grünwald-Giemsa staining. Supernatant was collected, frozen at $-70^{\circ} \mathrm{C}$, and later used for measurements of TNF- $\alpha$ concentration with the ELISA system (BioSource International, Camarillo, CA) and total protein concentration with BCA protein assay (Pierce Biotechnology, Rockford, IL). Lung tissue samples $(2 \times 2 \mathrm{~cm})$ were excised in a consistent manner from the lower lobes of both lungs, frozen at $-70^{\circ} \mathrm{C}$, and later used for the spectrophotometric assay of myeloperoxidase activity (26).

Analysis of regional ventilation. Regional ventilation was assessed with the DPI method, an image acquisition system based on digital capture and analysis of sequential fluoroscopic chest x-ray images (27). The imaging system consisted of a standard fluoroscopic unit connected to a computer with custom-programmed software. 
During a ventilation study, animals were supine on the examination table in a custom-built plastic holder. Care was taken to maintain the position between studies. Neither contrast media nor radioactive isotopes were used. Fluoroscopic anteroposterior chest images of $384 \times 288$ pixels with 256 gray shades were collected at 25 frames/s for $4 \mathrm{~s}$ and digitally stored on the computer. High voltage $(90-110 \mathrm{kVp})$ with a fixed $\mathrm{mA}$ value and a thick copper filtration $(1-3 \mathrm{~mm} \mathrm{Cu})$ were used to get the best contrast between aerated lung and soft tissues and avoid attenuation of the moving ribs. The total radiation dose $(\sim 0.1 \mathrm{mGy})$ is approximately the same as that in a normal chest $\mathrm{x}$-ray examination.

The image analysis of the fluoroscopic images was performed using a specially developed software (Venobs, version 4.0). One respiratory cycle was used for ventilation analysis to allow standardized procedure. Lungs were outlined from the end-expiratory image of the image series. Tracheal bifurcation was visualized, and lung regions cephalic to bifurcation were excluded from the analysis. An automatic lung detection mode then was used to roughly outline the lungs. After that, when necessary, the lungs were manually delineated to exclude areas outside the rib cage and diaphragm, and finally cardiac shadow was removed from the analysis. The outlined area was automatically divided into four regions of equal number of pixels, and the sum of the two most caudal regions was used in the analysis. From one ventilatory cycle of fluoroscopic anteroposterior chest images, the average (AVG) and the range of variation of pulmonary transmittance [amplitude (AMP)] in the aforementioned lower lung regions was measured. AVG is suggested to represent the average amount of alveolar gas and AMP the maximal change in pulmonary gas content during one respiratory cycle. Subsequently, the ratios in right to left lung (R/L) AVG and AMP ratios were calculated. Low ratio values indicate poor regional ventilation of the right lung.

Data analysis. Longitudinal data first were studied with ANOVA for repeated measures design with one between factor (group) and one within factor (time), and post hoc comparisons between groups were made with a nonpaired $t$ test. Significance between means of other data first were tested by ANOVA for repeated measurements with one between factor (group) and one within factor (side). When significant differences were noted, a Bonferroni adjusted paired $t$ test was used to compare right and left lungs, and a nonpaired $t$ test was used to compare instilled and noninstilled lungs between the study groups. A $p<0.05$ was considered statistically significant.

\section{RESULTS}

Mean arterial blood pressure was similar at baseline, decreased in both study groups $(p<0.001)$, and was lower in the PTX-treated than nontreated animals from 30 min onward (Fig. 1). In contrast, heart rate was higher in the PTX group than in the untreated group at 6 and $12 \mathrm{~h}$ (Fig. 1). The $\mathrm{AaDO}_{2}$ was not different at baseline and was equally increased during the study period $(p<0.001)$ in both groups (Fig. 1). Arterial $\mathrm{pH}$ was lower in the nontreated than in the PTX-treated piglets at 30 min and $1 \mathrm{~h}$, but thereafter no differences were found (data not
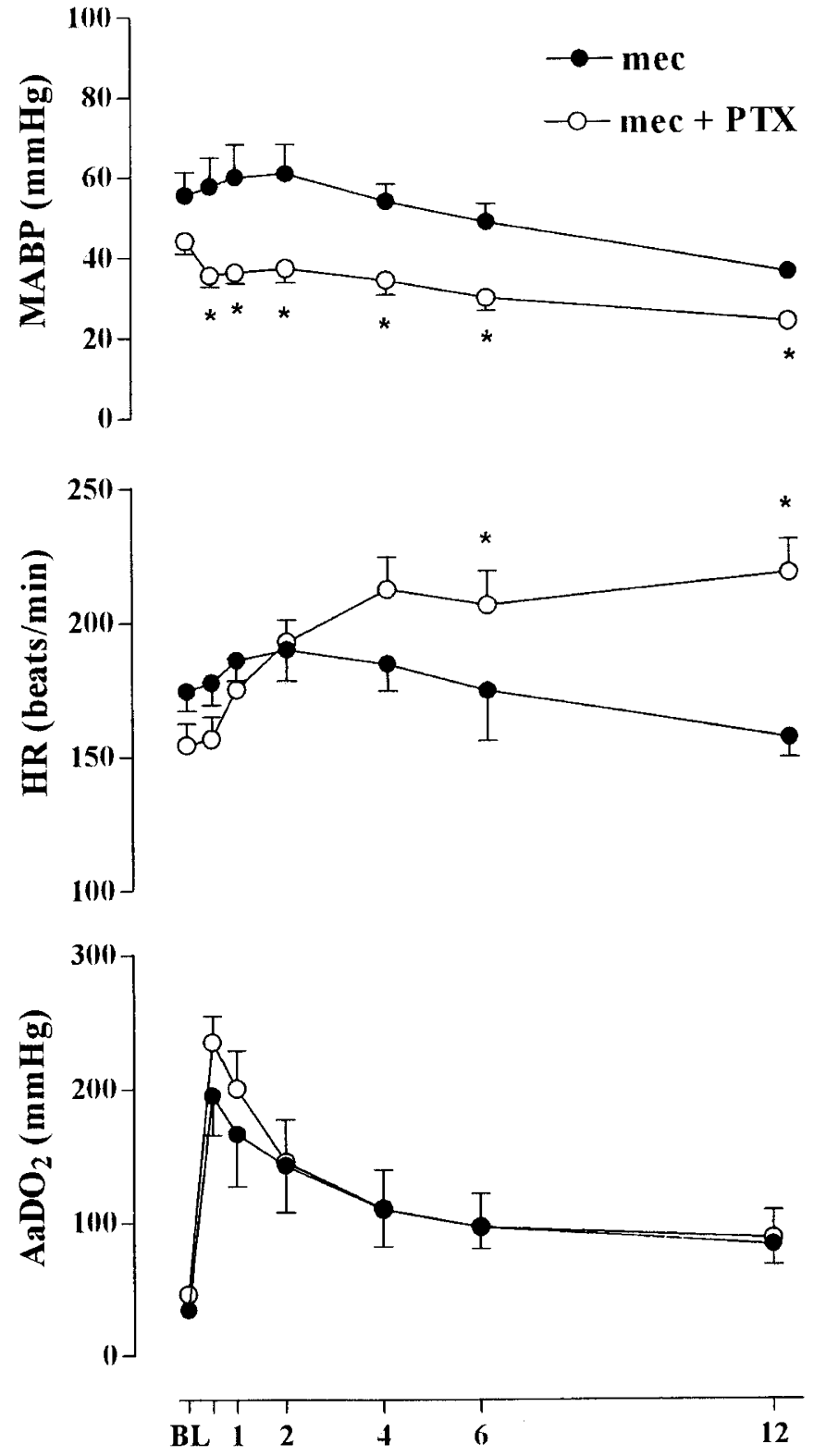

Time after meconium instillation (h)

Figure 1. Mean arterial blood pressure, heart rate, and $\mathrm{AaDO}_{2}$ )in eight untreated (mec) and nine PTX-treated (mec + PTX) newborn piglets after unilateral intrapulmonary instillation of meconium. Mean $\pm \mathrm{SEM} ;{ }^{*} p<0.05$ vs untreated group. BL, baseline.

shown). The meconium batch was sterile in culture, and its endotoxin content was $24 \mathrm{ng} / \mathrm{mg}$ of meconium.

Unilateral meconium instillation increased BAL fluid total cell and PMN counts locally in the instilled lungs, when compared with the contralateral lungs, but there were no differences in the counts between the PTX-treated and nontreated study groups (Table 1). Meconium also increased alveolar macrophage count in the contaminated lungs, compared with contralateral lungs, but this effect was not seen after PTX treatment (Table 1). Unilateral meconium contamination increased BAL fluid TNF- $\alpha$ and protein concentrations locally in the exposed lungs, when compared with contralateral lungs, but the values were significantly lower in the PTX-treated 
Table 1. BAL fluid total cell, PMN, and macrophage counts $\left(\times 10^{6} / \mathrm{mL}\right) ; B A L$ fluid $T N F-\alpha(\mathrm{pg} / \mathrm{mL})$ and total protein $(\mathrm{mg} / \mathrm{mL})$ concentrations; and lung tissue MPO activity (units/mg prot) in eight untreated (mec) and nine PTX-treated (mec + PTX) newborn piglets 12 hours after unilateral intrapulmonary instillation of meconium

\begin{tabular}{|c|c|c|c|c|c|c|}
\hline & Total cell count & PMN count & Macrophage count & TNF- $\alpha$ concentration & Protein concentration & MPO activity \\
\hline \multicolumn{7}{|l|}{$\mathrm{Mec}$} \\
\hline Instilled lung & $\begin{array}{c}12.0 \pm 7.3 * \\
(3.6-24.2)\end{array}$ & $\begin{array}{l}7.5 \pm 5.8^{*} \\
(3.0-19.9)\end{array}$ & $\begin{array}{c}3.1 \pm 2.8^{*} \\
(0.4-7.7)\end{array}$ & $\begin{array}{c}42.2 \pm 22.1 * \\
(21.1-86.8)\end{array}$ & $\begin{array}{r}1.1 \pm 0.3 * \\
(0.7-1.7)\end{array}$ & $\begin{array}{c}1.6 \pm 1.0 * \\
(0.4-3.5)\end{array}$ \\
\hline Noninstilled lung & $\begin{array}{l}2.1 \pm 2.2 \\
(0.3-6.9)\end{array}$ & $\begin{array}{c}1.0 \pm 1.2 \\
(0.1-3.8)\end{array}$ & $\begin{array}{c}0.6 \pm 0.5 \\
(0.1-1.5)\end{array}$ & $\begin{array}{c}21.6 \pm 4.9 \\
(16.1-28.7)\end{array}$ & $\begin{array}{l}0.5 \pm 0.3 \\
(0.2-1.2)\end{array}$ & $\begin{array}{c}0.4 \pm 0.3 \\
(0.1-0.9)\end{array}$ \\
\hline \multicolumn{7}{|l|}{ mec + PTX } \\
\hline Instilled lung & $\begin{array}{l}6.2 \pm 3.5^{*} \\
(2.3-11.7)\end{array}$ & $\begin{array}{l}4.7 \pm 2.7^{*} \\
(1.9-10.3)\end{array}$ & $\begin{array}{r}0.9 \pm 0.7 \\
(0.1-2.3)\end{array}$ & $\begin{array}{c}17.4 \pm 5.0^{* \dagger}+ \\
(9.8-25.4)\end{array}$ & $\begin{array}{c}0.6 \pm 0.2 * \dagger \\
(0.4-0.9)\end{array}$ & $\begin{array}{c}1.5 \pm 0.2 * \\
(1.1-1.7)\end{array}$ \\
\hline Noninstilled lung & $\begin{array}{l}\qquad \begin{array}{l}1.4 \pm 1.1 \\
(0.1-4.0)\end{array} \\
\text { group, } p=0.244 \\
\text { side, } p<0.001 \\
\text { interaction, } p=0.428\end{array}$ & $\begin{array}{l}1.0 \pm 0.9 \\
(0.1-2.8) \\
\text { group, } p=0.679 \\
\text { side, } p<0.001 \\
\text { interaction, } p=0.339\end{array}$ & $\begin{array}{l}\quad 0.3 \pm 0.3 \\
\quad(0.0-1.0) \\
\text { group, } p=0.020 \\
\text { side, } p<0.001 \\
\text { interaction, } p=0.470\end{array}$ & $\begin{array}{l}\qquad .2 \pm 1.9 \neq \\
\quad(5.9-10.4) \\
\text { group, } p=0.002 \\
\text { side, } p<0.001 \\
\text { interaction, } p=0.361\end{array}$ & $\begin{array}{l}\quad 0.2 \pm 0.1 \\
\quad(0.1-0.4) \\
\text { group, } p<0.001 \\
\text { side, } p<0.001 \\
\text { interaction, } p=0.036\end{array}$ & $\begin{array}{l}\quad \begin{array}{l}0.4 \pm 0.1 \\
(0.2-0.7)\end{array} \\
\text { group, } p=0.446 \\
\text { side, } p<0.001 \\
\text { interaction, } p=0.609\end{array}$ \\
\hline
\end{tabular}

Data are mean $\pm \mathrm{SD}$ (range). MPO, myeloperoxidase.

$* p<0.05$ vs contralateral lung.

$\dagger p<0.05$ vs nontreated meconium instilled lung.

$\ddagger p<0.05$ vs nontreated noninstilled lung.

group (Table 1). In fact, BAL fluid TNF- $\alpha$ concentration was undetectable in one PTX-treated/meconium-instilled lung, three nontreated/noninstilled lungs, and five PTX-treated/ noninstilled lungs, and the concentrations were significantly lower also in the noninstilled lungs of the PTX-treated compared with the nontreated study group (Table 1). Similar to BAL fluid total cell and PMN counts, lung tissue myeloperoxidase activity was higher in the meconium-instilled than noninstilled lungs, and PTX treatment did not affect these values (Table 1).

R/L AVG decreased $(p<0.001)$ similarly $(p=0.220)$ in both groups during the study period (Fig. 2, top). Similarly, R/L AMP decreased $(p<0.001)$ initially in both groups, but there was an interaction $(p=0.023)$ between the groups and the values were lower in the nontreated than in the PTX-treated piglets at 4, 6, and $12 \mathrm{~h}$ (Fig. 2, bottom).

\section{DISCUSSION}

Initial deterioration in neonatal lung mechanics after aspiration of meconium is supposed to be mainly obstructive, caused by thick or particulate meconium blocking the airways partially or completely $(3,6)$. Experimental investigations have shown that dynamic lung compliance drops rapidly during the first hour after meconium insufflation and remains low for the first days after the insult $(3,6)$. Whereas the initial perturbation in global pulmonary mechanics after meconium insult may be due to widespread obstruction of the airways and uneven lung aeration (3), the subsequent phase of sustained pulmonary dysfunction is characterized by progressively developing inflammatory reaction within the lung tissue (6). In line with these findings, the earliest disturbance of regional pulmonary ventilation in the meconium-contaminated lung area in our study was reflected in ipsilaterally registered decrease of ventilation amplitude. This variable of the DPI examination, indicating the variation in the transmitted radiation during the ventilatory expansion of the defined lung region, is in fact demonstrated to be low when the specific lung region is functionally or anatomically obstructed (28). Similarly, the sustained low DPI amplitude after the initial obstructive phase
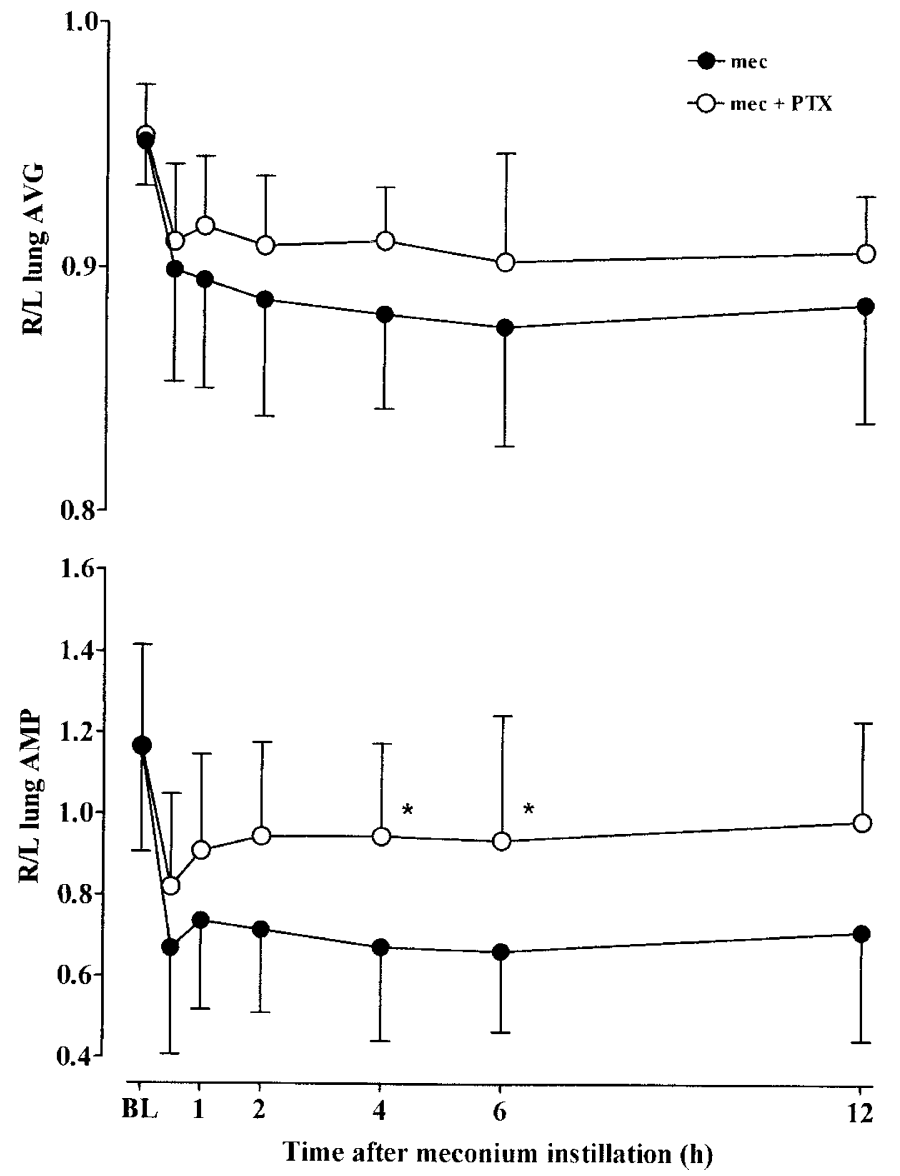

Figure 2. R/L ventilation $A V G$ and AMP in eight untreated (mec) and nine PTX-treated (mec + PTX) newborn piglets after unilateral (right lung) meconium instillation. Mean $\pm \mathrm{SD} ;{ }^{*} p<0.05$ vs untreated group. BL, baseline.

in meconium-exposed lungs may reflect the developing pulmonary inflammation with local neutrophil and fluid accumulation, reported to be present already at $4-6 \mathrm{~h}$ after meconium aspiration $(6,29,30)$. The lowest regional aeration values, represented as reduced AVG in our study, are also compatible with this exudative phase of patchy consolidation or atelectasis in the meconium-contaminated pulmonary tissue. As evident 
from our data, the inflammatory reaction is associated with migration of activated macrophages and neutrophils, production of inflammatory cytokines, and increased vascular permeability with potential inactivation of pulmonary surfactant contributing to significant impairment of lung function $(6,31,32)$. Direct inhibition of lung surfactant by meconium supposedly also contributes to the ventilation insufficiency $(4,5)$, but initially, during the first $2 \mathrm{~h}$ after aspiration, it is considered to be of minor importance (3). The endotoxin content of meconium was in the nanomolar range, which is well below the amount required for induction of significant pulmonary neutrophil influx.

The effects of anti-inflammatory agents, specifically glucocorticoids, in the treatment of MAS have been variable and often unsuccessful. Although steroids may improve oxygenation and lung function in clinical and experimental trials $(10,33)$, the significance of their anti-inflammatory action for the improved ventilatory status in MAS is still unclear (11). In fact, there is evidence indicating that steroids may diminish vascular permeability in the meconium-exposed lungs, but no clear effect on the inflammatory cellular response in the pulmonary tissue has been shown $(8,11,34)$. Similar to these findings, the present results demonstrate that PTX has no significant effect on the neutrophil number or activity in the meconium-exposed lung areas, despite being able to inhibit local activation and migration of inflammatory cells in various other lung injury models (19-23). However, PTX administration effectively suppressed the meconium-induced increase in alveolar macrophage number and local TNF- $\alpha$ production in the insulted lungs. The cause of this variable effect of PTX on the pulmonary inflammatory cells in our model remains uncertain, but it is probable that, unlike after acid aspiration (35), local TNF- $\alpha$ production by alveolar macrophages is not essential for the early neutrophil migration in meconium-exposed lungs. However, TNF- $\alpha$ is able to induce increased pulmonary permeability and reduced surfactant production and is thereby supposed to be involved in the pathogenesis of the various lung injuries, including meconium-induced pulmonary damage (36-40). As also evident from our data, these lung injury processes are effectively prevented by PTX $(41,42)$ and thus may contribute to the improved ventilatory function in the meconium-contaminated areas of the treated neonatal lungs. Although PTX additionally may have significant hemodynamic properties, the reduction of permeability damage is unlikely attributed to alterations in pulmonary microvascular pressure (22). In fact, in line with our results, PTX has been shown to preserve lung compliance in an experimental injury model despite significant neutrophil sequestration (43). This mechanism of PTX on lung function is further underscored by the observation that PTX was unable to affect the initial meconium-induced obstructive phase but significantly prevented the impairment of local ventilation from $4 \mathrm{~h}$ onward after the meconium insult, a phase characterized by the progressive localized pulmonary inflammatory reaction (6).

Although our present data indicate that regional pulmonary inflammatory and ventilatory disturbances after meconium aspiration may be diminished by PTX treatment, prompt obstetric and pediatric suctioning of the upper and lower airways still remains the critical procedure in reduction of the severity of MAS. This is especially important when amniotic fluid is stained with thick or particulate meconium (1). Once meconium has entered the airways, amelioration of surfactant dysfunction with surfactant replacement or lavage and augmentation of the developing lung inflammatory reaction with antiinflammatory therapy, such as corticosteroid treatment, have been proposed to be beneficial (1). Our present results additionally indicate that early treatment of MAS with PTX could be a new, pathophysiologically plausible therapeutic alternative. However, as indicated by our data, systemic hemodynamics must be monitored closely in newborns with PTX treatment.

\section{CONCLUSION}

In conclusion, PTX treatment has no clear effect on neutrophil influx but decreases the number of intra-alveolar macrophages, TNF- $\alpha$ production, and alveolocapillary permeability in the meconium-contaminated areas of neonatal lungs. Because these local effects are associated with simultaneous improvement of the regional pulmonary ventilation, targeted anti-inflammatory approaches with PTX may be of benefit in the treatment of respiratory failure in severe MAS.

\section{REFERENCES}

1. Cleary GM, Wiswell TE 1998 Meconium-stained amniotic fluid and the meconium aspiration syndrome. An update. Pediatr Clin North Am 45:511-529

2. Wiswell TE, Bent RC 1993 Meconium staining and the meconium aspiration syndrome. Unresolved issues. Pediatr Clin North Am 40:955-981

3. Tran N, Lowe C, Sivieri EM, Shaffer TH 1980 Sequential effects of acute meconium obstruction on pulmonary function. Pediatr Res 14:34-38

4. Clark DA, Nieman GF, Thompson JE, Paskanik AM, Rokhar JE, Bredenberg CE 1987 Surfactant displacement by meconium free fatty acids: an alternative explanation for atelectasis in meconium aspiration syndrome. J Pediatr 110:765-770

5. Moses D, Holm BA, Spitale P, Liu MY, Enhorning G 1991 Inhibition of pulmonary surfactant function by meconium. Am J Obstet Gynecol 164:477-481

6. Davey AM, Becker JD, Davis JM 1993 Meconium aspiration syndrome: physiological and inflammatory changes in a newborn piglet model. Pediatr Pulmonol 16:101108

7. Kojima T, Hattori K, Fujiwara T, Sasai-Takedatsu M, Kobayashi Y 1994 Meconiuminduced lung injury mediated by activation of alveolar macrophages. Life Sci 54:1559-1562

8. Frantz ID, Wang NS, Thach BT 1975 Experimental meconium aspiration: effects of glucocorticoid treatment. J Pediatr 86:438-441

9. Yeh TF, Srinivasan G, Harris V, Pildes RS 1977 Hydrocortisone therapy in meconium aspiration syndrome: a controlled study. J Pediatr 90:140-143

10. Khan AM, Shabarek FM, Kutchback JW, Lally KP 1999 Effects of dexamethasone on meconium aspiration syndrome in newborn piglets. Pediatr Res 46:179-183

11. Holopainen R, Laine J, Halkola L, Aho H, Kaapa P 2001 Dexamethasone treatment attenuates pulmonary injury in piglet meconium aspiration. Pediatr Res 49:162-168

12. Wiswell TE 2001 Advances in the treatment of the meconium aspiration syndrome. Acta Paediatr Suppl 90:28-30

13. Dettelbach HR, Aviado DM 1985 Clinical pharmacology of pentoxifylline with special reference to its hemorrheologic effect for the treatment of intermittent claudication. J Clin Pharmacol 25:8-26

14. Mandell GL 1995 Cytokines, phagocytes, and pentoxifylline. J Cardiovasc Pharmacol 25 Suppl 2:S20-S22

15. Sullivan GW, Carper HT, Novick WJ Jr, Mandell GL 1988 Inhibition of the inflammatory action of interleukin-1 and tumor necrosis factor (alpha) on neutrophil function by pentoxifylline. Infect Immun 56:1722-1729

16. Mandell GL 1988 ARDS, neutrophils, and pentoxifylline. Am Rev Respir Dis 138:1103-1105

17. Raffin TA 1990 Acute lung injury and pentoxifylline. Crit Care Med 18:1485-1486

18. Albertson TE, Marelich GP 1998 Pharmacologic adjuncts to mechanical ventilation in acute respiratory distress syndrome. Crit Care Clin 14:581-610

19. Welsh CH, Lien D, Worthen GS, Weil JV 1988 Pentoxifylline decreases endotoxininduced pulmonary neutrophil sequestration and extravascular protein accumulation in the dog. Am Rev Respir Dis 138:1106-1114

20. Lindsey HJ, Kisala JM, Ayala A, Lehman D, Herdon CD, Chaudry IH 1994 Pentoxifylline attenuates oxygen-induced lung injury. J Surg Res 56:543-548 
21. Lilly CM, Sandhu JS, Ishizaka A, Harada H, Yonemaru M, Larrick JW, Shi TX, O'Hanley PT, Raffin TA 1989 Pentoxifylline prevents tumor necrosis factor-induced lung injury. Am Rev Respir Dis 139:1361-1368

22. Seear MD, Hannam VL, Kaapa P, Raj JU, O’Brodovich HM 1990 Effect of pentoxifylline on hemodynamics, alveolar fluid reabsorption, and pulmonary edema in a model of acute lung injury. Am Rev Respir Dis 142:1083-1087

23. Kudoh I, Ohtake M, Nishizawa H, Kurahashi K, Hattori S, Okumura F, Pittet JF, Wiener-Kronish J 1995 The effect of pentoxifylline on acid-induced alveolar epithelial injury. Anesthesiology 82:531-541

24. Korhonen K, Soukka H, Halkola L, Peuravuori H, Aho H, Pulkki K, Kero P, Kaapa PO 2003 Meconium induces only localized inflammatory lung injury in piglets. Pediatr Res 54:192-197

25. Holopainen R, Soukka H, Halkola L, Kaapa P 1998 Meconium aspiration induces a concentration-dependent pulmonary hypertensive response in newborn piglets. Pediatr Pulmonol 25:107-113

26. Grisham MB, Benoit JN, Granger DN 1990 Assessment of leukocyte involvement during ischemia and reperfusion of intestine. Methods Enzymol 186:729-742

27. Kiuru A, Svedstrom E, Kuuluvainen I 1991 Dynamic imaging of pulmonary ventilation. Description of a novel digital fluoroscopic system. Acta Radiol 32:114-119

28. Svedstrom EJ, Kiuru A, Puhakka HJ 1990 Dynamic imaging of pulmonary ventilation in children using digital subtraction radiography. Acta Radiol 31:53-58

29. Tyler DC, Murphy J, Cheney FW 1978 Mechanical and chemical damage to lung tissue caused by meconium aspiration. Pediatrics 62:454-459

30. Soukka H, Rautanen M, Halkola L, Kero P, Kaapa P 1997 Meconium aspiration induces ARDS-like pulmonary response in lungs of ten-week-old pigs. Pediatr Pulmonol 23:205-211

31. Strieter RM, Kunkel SL 1994 Acute lung injury: the role of cytokines in the elicitation of neutrophils. J Investig Med 42:640-651

32. Fujishima S, Aikawa N 1995 Neutrophil-mediated tissue injury and its modulation. Intensive Care Med 21:277-285

33. da Costa DE, Nair AK, Pai MG, Al Khusaiby SM 2001 Steroids in full term infant with respiratory failure and pulmonary hypertension due to meconium aspiration syndrome. Eur J Pediatr 160:150-153
34. Soukka H, Halkola L, Aho H, Rautanen M, Kero P, Kaapa P 1997 Methylprednisolone attenuates the pulmonary hypertensive response in porcine meconium aspiration. Pediatr Res 42:145-150

35. Goldman G, Welbourn R, Kobzik L, Valeri CR, Shepro D, Hechtman HB 1990 Tumor necrosis factor-alpha mediates acid aspiration-induced systemic organ injury. Ann Surg 212:513-519

36. Zagariya A, Bhat R, Uhal B, Navale S, Freidine M, Vidyasagar D 2000 Cell death and lung cell histology in meconium aspirated newborn rabbit lung. Eur J Pediatr 159:819-826

37. Stephens KE, Ishizaka A, Larrick JW, Raffin TA 1988 Tumor necrosis factor causes increased pulmonary permeability and edema. Comparison to septic acute lung injury. Am Rev Respir Dis 137:1364-1370

38. Imai Y, Kawano T, Iwamoto S, Nakagawa S, Takata M, Miyasaka K 1999 Intratracheal anti-tumor necrosis factor-alpha antibody attenuates ventilator-induced lung injury in rabbits. J Appl Physiol 87:510-515

39. Balibrea-Cantero JL, Arias-Diaz J, Garcia C, Torres-Melero J, Simon C, Rodriguez JM, Vara E 1994 Effect of pentoxifylline on the inhibition of surfactant synthesis induced by TNF-alpha in human type II pneumocytes. Am J Respir Crit Care Med 149:699-706

40. Jones CA, Cayabyab RG, Kwong KY, Stotts C, Wong B, Hamdan H, Minoo P, deLemos RA 1996 Undetectable interleukin (IL)-10 and persistent IL-8 expression early in hyaline membrane disease: a possible developmental basis for the predisposition to chronic lung inflammation in preterm newborns. Pediatr Res 39:966-975

41. Zabel P, Schade FU 1994 Pentoxifylline and tumour necrosis factor-induced lung injury. Eur Respir J 7:1389-1391

42. Marques LJ, Zheng L, Poulakis N, Guzman J, Costabel U 1999 Pentoxifylline inhibits TNF-alpha production from human alveolar macrophages. Am J Respir Crit Care Med 159:508-511

43. Creamer KM, McCloud LL, Fisher LE, Ehrhart IC 2001 Pentoxifylline rescue preserves lung function in isolated canine lungs injured with phorbol myristate acetate. Chest 119:1893-1900 